\title{
LOCALIZATION OF GLYCINE-2-C ${ }^{14}$ INJECTED INTO ADULT FEMALE FROGS ${ }^{1}$
}

\author{
NORMAN E. KEMP \\ Department of Zoology, University of Michigan, Ann Arbor, and \\ Division of Biological and Medical Research, Arganne \\ National Laboratory, Lemont, Illinois \\ THIRTEEN FIGURES
}

Radioactive amino acids labeled with $\mathrm{C}^{14}$ or $\mathrm{S}^{35}$ have proved to be extremely valuable tools for the biochemist investigating the metabolism of proteins in a variety of biological systems, both in vivo and in vitro (Borsook, '50; Lee, Anderson, Miller and Williams, '51; Borsook, Deasy, Haagen-Smit, Keighley and Lowy, '52; Christensen, Riggs and Ray, '52; Mueller, '53; Ficq, Gavosto and Errera, '54a, '54b; Zamecnik and Keller, '54). The discoveries that fetal and malignant tissues incorporate amino acids to a greater extent than normal tissues in the adult (Friedberg, Shulman and Greenberg, '48; Christensen and Streicher, '48; Zamecnik, Frantz, Jr., Loftfield and Stephenson, '48; Christensen, Riggs, Fischer and Palatine,'52) are provocative to the embryologist, and have stimulated a series of investigations on protein synthesis and its relation to development in the amphibian embryo (Friedberg and Eakin, '49; Eakin, Berg and Kutsky, '50; Eakin, Kutsky and Berg, '51; Kutsky, Eakin, Berg and Kavanau, '53).

The present study stemmed from the author's interest in the synthesis of yolk in the developing oocytes of the frog, since the yolk platelets of Amphibia are rich in proteins, including phosphoproteins and probably nucleoproteins

1 Work performed at Argonne National Laboratory under the auspices of the U. S. Atomic Energy Commission, and at the University of Michigan with the support of grants from the National Science Foundation (G1166) and the Michigan Memorial - Phoenix Project. 
(Brachet, '50; Grant, '53; Barth and Barth, '54). The expectation that the concentration of radioactive glycine might be used to demonstrate the synthesis of yolk in the oocyte was borne out in an exploratory experiment (Kemp, '54, '55). Further data on utilization of glycine by the enlarging ovary are included in this report, together with comparative data on incorporation of this amino acid into other organs of the female frog.

\section{MATERIALS AND METIIODS}

Forty-two adult female frogs, including 12 used in the exploratory experiment previously mentioned (Kemp, op. cit.), were injected intrapleuroperitoneally with glycine-2-C $\mathrm{C}^{14}$ dissolved in distilled water. Fourteen received approximately $20 \mu \mathrm{c}$ and the remainder $10 \mu \mathrm{c}$. After injection the animals were kept 1 to 5 days on wet paper toweling in individual gallon jars with screw-capped lids. At the time of sacrifice animals were removed from the jars with the right hand and wrapped in a dry paper towel held in the left hand to prevent escape; then they were pithed. From the group of 12 animals used in the first experiment, samples of stomach, liver, intestine, kidney, ovary, lung, brain and heart (see Kemp, '55) were fixed in Bouin's fluid for sectioning. Duplicate samples of each organ (brain excepted), as well as samples of blood collected from the ventricle, were homogenized with $10 \%$ trichloracetic acid in a Ten Broeck grinder in order to precipitate proteins. The same procedure was followed for the remaining 30 animals injected during the summer of 1954 at the Argonne National Laboratory, except that the organs preserved or homogenized were stomach, liver, intestine, kidney, ovary, skin and gastrocnemius muscle. With the intent of obtaining successively older stages in growth of oocytes in the ovary, 7 animals in the 1954 series were injected on June 25, 8 each on July 9 and July 23, and 7 on August 23. Later histological examination revealed that all of the June 25 group were in stage $\mathrm{Y}_{0}$ (Kemp, '53) with respect to deposition of yolk in the oocytes; some in the July 9 and July 23 
groups had reached stage $Y_{2}$ or $Y_{3}$; most in the August 23 group were in late stage $Y_{3}$ or in stage $Y_{4}$ at the time of injection.

Fixed tissue was embedded in paraffin and cut at $10 \mu$. Ribbons were divided into lengths of 4 sections and either one or two rows mounted on standard slides. One slide representative of each tissue for each animal was stained with Harris' hematoxylin and eosin. Another slide bearing closely similar sections was used to make an autoradiogram on a piece of Eastman No-Screen Medical X-Ray Film cut to the size of an ordinary microscopic slide. The film was sandwiched between a blank slide and the tissue-bearing slide and held firmly in position by means of a tight elastic band or a binder's clip (Dent and Hunt, '52); time of exposure was 4 days. By superimposing the developed autoradiograms over matching stained sections one could easily detect the intracellular position of localizations of radioactivity.

Purification of precipitated proteins was accomplished by the procedure of Levine and Tarver ('50) as communicated by Doctor Levine, namely: (1) precipitate with $10 \%$ trichloracetic acid (TCA) and centrifuge; (2) wash with 5\% TCA, resuspend and let stand; (3) heat at $90^{\circ} \mathrm{C}$. in $5 \%$ TCA for 15 minutes to remove nucleic acids; (4) repeat heat treatment with $5 \%$ TCA for 5 minutes to remove all glycogen; (5) heat in $100 \%$ alcohol to boiling $\left(78.5^{\circ} \mathrm{C}\right.$.) to remove lipids and water; (6) wash twice with a mixture of three parts $100 \%$ alcohol to one part ether to remove excess TCA; (7) wash with ether alone to remove alcohol; (8) remove ether in water bath at $40^{\circ} \mathrm{C}$; (9) dry in oven at $105^{\circ} \mathrm{C}$. for two hours, then store in vial; (10) grind protein in agate mortar with plain ether; (11) pipette ground protein with petroleum ether into cylinder and platemaker, agitate and let settle evenly; (12) evaporate petroleum ether slowly under infra-red lamp; (13) dry the plated sample at $105^{\circ} \mathrm{C}$. for one and one-half hours to equilibrate before weighing, and determine the radioactivity. Samples were counted with a thin, end-window GeigerMüller tube (Tracerlab TGC-2) connected with a Raychronix 
64-scaler manufactured by Radioactive Products, Inc. Corrections were made for background, coincidence and selfabsorption before calculating specific activities. For accurate comparison of counts made on different days, a $\mathrm{C}^{14}$ source obtained from Oak Ridge National Laboratory was used as a reference standard.

I wish to express my appreciation to Dr. T. N. Tahmisian of Argonne National Laboratory for the opportunity to work in his laboratory during the summers of 1954 and 1955. I am also indebted to Mr. Walter Kisieleski, Argonne National Laboratory, and Dr. Melvin Levine, University of Michigan, for technical advice, and to Mrs. Margaret D. Allen for technical assistance.

\section{RESULTS \\ Autoradiograms}

Autoradiograms obtained from an example of each of the organs studied are shown in plate 1 . It is at once apparent that marked localization of radioactivity occurred in certain organs. Mucosal cpithelium of stomach and intestine (figs. 2 and 3) was particularly active, while the visceral muscle or connective tissue in these organs was only moderate or low in activity. Likewise, radioactivity was highly concentrated in the epidermal epithelium (fig. 9) but only slightly in the connective tissue of the dermis. Liver, lung, kidney, heart, brain, and skeletal muscle (figs. 1, 4, 5, 6, 7 and 8) took up the glycine in different amounts but nearly uniformly through each tissue. In muscle (fig. 8) one can see small circular areas which are darker around the periphery than in the interior. These areas may possibly correspond to cross-sections of individual muscle fibers.

Uptake in the ovary at stages $\mathrm{Y}_{0}, \mathrm{Y}_{2} \mathrm{Y}_{3}$ and $\mathrm{Y}_{4}$ is visualized in figures 10-13. Incorporation of the glycine into individual oocytes can be detected at stage $Y_{0}$ (fig. 10), but the distinct 
localization seen in later stages (figs. 11-13) is not yet apparent. Unquestionably this peripheral zone of high radioactivity in oocytes synthesizing yolk means that synthetic activity is much greater here than in the interior of the cell. It is significant that this region of high anabolic activity remains at the periphery even after the cytoplasm has become filled with yolk (fig. 13).

\section{Radioactivity of isolated proteins}

In table 1 are recorded the specific activities of the proteins isolated from 30 animals injected in the summer of 1954 . The stage of deposition of yolk is included (column 3) primarily for comparison with the counts on ovarian proteins. Examination of the table will reveal that counts made on animals injected with $20 \mu \mathrm{c}$ are generally higher than for those receiving $10 \mu \mathrm{c}$, although the magnitude of the difference varies considerably. Because of the variable counts in different animals receiving the same dosage, an objective attempt was made to judge the relative order of radioactivity in each of the 7 organs here considered. This was done by listing for each organ its order of activity with respect to the order for other organs in the same animal. For example, in animal number 1 , skin gave the highest count and accordingly was given a rating of 1 . Stomach with the lowest count in this animal rated a 7 . After these ratings had been assigned for all animals, those for a given organ were added and the sum divided by 30 to give an average rating. According to this scheme skin received a top rating of 1.75 , and the other organs followed in the sequence of kidney (2.1), ovary (3.5), intestine (3.9), liver (4.1), stomach (5.87), and muscle (6.76). Liver and intestine are reversed in order from that reported in the earlier experiment (Kemp, '55), but their activity is not greatly different.

\section{DISCUSSION AND CONCLUSIONS}

Both in the rat (Greenberg and Winnick, '48; Winnick, Friedberg and Greenberg, '48) and the frog (Kemp, '55; 
TABLE 1

Specific activity (counts/min $\mathrm{mg}$ ) of isolated protein from organs of 30 animals injected with radioactive glycine and sacrificed 4 days tater

\begin{tabular}{rrrrrrrrrr}
\hline & & & & & & \\
\\
June
\end{tabular}

July 9

$\begin{array}{rrlrrrrrrr}8 & 20 & Y_{2}-Y_{3} & 988 & 143 & 248 & 150 & 165 & 95 & 12 \\ 9 & 20 & Y_{0} & 304 & 308 & 96 & 198 & 239 & 106 & 57 \\ 10 & 10 & Y_{3}-Y_{2} & 384 & 316 & 586 & 185 & 215 & 71 & 43 \\ 11 & 10 & Y_{0} & 164 & 167 & 95 & 63 & 133 & 74 & 22 \\ 12 & 10 & Y_{3}-Y_{2} & 204 & 241 & 365 & 137 & 161 & 58 & 30 \\ 13 & 10 & Y_{0} & 285 & 231 & 161 & 154 & 183 & 62 & 40 \\ 14 & 10 & Y_{0} & 220 & 290 & 128 & 153 & 212 & 70 & 59 \\ 15 & 10 & Y_{2}-Y_{3} & 49 & 69 & 84 & 44 & 40 & 29 & 12\end{array}$

July 23

$\begin{array}{rrllrrrrrr}16 & 20 & Y_{0} & & 391 & 256 & 205 & 142 & 73 & 19 \\ 17 & 20 & Y_{0} & 585 & 555 & 226 & 341 & 347 & 73 & 14 \\ 18 & 20 & \text { Testis } & 100 & 159 & 349 & 90 & 75 & 27 & 7 \\ 19 & 10 & Y_{1}-Y_{2} & 225 & 216 & 26 & 84 & 143 & 40 & 7 \\ 20 & 10 & Y_{0} & 216 & 201 & 104 & 160 & 117 & 39 & 6 \\ 21 & 10 & Y_{0} & 255 & 148 & 87 & 95 & 63 & 37 & 8 \\ 22 & 10 & Y_{1}-Y_{2} & 119 & 111 & 60 & 90 & 55 & 29 & 6 \\ 23 & 10 & Y_{2} & 140 & 87 & 68 & 22 & 70 & 13 & 169\end{array}$

August 23

\begin{tabular}{rrlrrrrrrr}
24 & 20 & $\mathrm{Y}_{3}-\mathrm{Y}_{4}$ & 434 & 368 & 329 & 236 & 184 & 162 & 22 \\
25 & 20 & $\mathrm{Y}_{3}-\mathrm{Y}_{4}$ & 233 & 249 & 288 & 141 & 163 & 115 & 18 \\
26 & 10 & $\mathrm{Y}_{3}-\mathrm{Y}_{4}$ & 119 & 134 & 231 & 68 & 78 & 60 & 8 \\
27 & 10 & $\mathrm{Y}_{0}$ & 252 & 286 & 80 & 180 & 108 & 104 & 13 \\
28 & 10 & $\mathrm{Y}_{0}$ & 200 & 177 & 88 & 188 & 117 & 103 & 22 \\
29 & 10 & $\mathrm{Y}_{4}$ & 161 & 140 & 179 & 82 & 101 & 57 & 19 \\
30 & 10 & $\mathrm{Y}_{4}$ & 82 & 37 & 67 & 76 & 63 & 45 & 30 \\
\hline
\end{tabular}


table 1 , this paper), kidney, liver and intestine rate relatively high in the order of activity of organs incorporating injected radioactive glycine into proteins. After the onset of vitellogenesis in developing oocytes, the ovary of the frog begins to compete on more equal terms with these active organs. Of all the organs examined, skin is the most active, and skeletal muscle the least active, with respect to uptake of glycine into proteins of the frog.

With the autoradiographic technique used, distinct localization of radioactivity is detectable in the epithelium of stomach and intestine, in growing oocytes in the ovary, and in the epidermis of the skin. All of these are undoubtedly sites of high anabolic activity; but in view of the devious metabolic pathways open to glycine, e.g., incorporation into purines (Abrams, Hammarsten and Shemin, '48), one wonders whether autoradiograms of sectioned tissue actually reveal incorporation of the amino acid into protein.

One way to test whether the radioactivity in sections is chiefly due to protein would be to compare Geiger counts made on sections with those made on isolated protein. Such a comparison was made for both ovary and kidney in the present study. Specific activities of the protein in both these organs, obtained from table 1 , were arranged in order from the lowest to the highest, and the order of relative activity recorded in a list opposite the number of each animal. Similar lists were made from counts made on sections. The two lists for the ovary, one on radioactivity of proteins and one on sections, were then compared, and similarly the two lists for the kidney. For the ovary, 5 of the animals in the lowest 10 with respect to order of activity of proteins were also in the lowest 10 with respect to activity of sections; 5 in the middle 10 for activity of proteins were also in the middle 10 for sections; and 8 animals were among the top 10 of both lists. For the kidney, 6 animals were in the lowest 10,6 in the middle 10, and 6 in the top 10 of both lists. Although the correspondence was not perfect, it was better than would be expected from chance alone; accordingly, it was concluded 
that total radioactivity of the sections was elosely related to the radioactivity of the constituent proteins. Since this is true, it is believed that the uptake of glycine-2- $\mathrm{C}^{14}$ in tissues, as demonstrated by autoradiograms, may be used to detect localization of active protein synthesis, even though the test cannot be considered necessarily specific for proteins.

A feature of interest in this study was the relative radioactivity of oocytes at different stages of deposition of yolk. Because of the variable counts in different animals (table 1 ), animals were compared with respect to the ratio between the count for ovary and that for skin, which usually had the highest count. Among the animals injected on June 25, all of which had oocytes in stage $Y_{0}$, none exceeded a ratio of 1.0 and only two were above 0.7. In the group of 8 animals injected on July 9 , three animals (10,12 and 15) beyond stage $Y_{0}$ had ratios well above 1.0, although one such animal (8) had a low ratio. All of the 8 animals of the July 23 group had low ratios (less than 0.5) even though three of them had oocytes at stage $\mathrm{Y}_{1}$ or $\mathrm{Y}_{2}$. Probably animals of this group were undernourished and therefore not synthesizing yolk rapidly. In the group injected on August 23, the 5 animals with oocytes at stage $Y_{3}$ or $Y_{4}$ all had ratios over 0.7 , whereas the two at stage $Y_{0}$ had low ratios. These figures support the conclusion that animals prior to the initiation of yolk deposition incorporate glycine into the oocyte at a low rate compared with that in animals actively synthesizing yolk.

It cannot properly be concluded from these-results that glycine is taken up directly into the yolk platelets of growing oocytes. It is obvious from a comparison of figures $10-13$ that uptake continues to occur chiefly in the peripheral cytoplasm even after yolk comes to fill the entire cytosome. We know that this peripheral active zone of incorporation of glycine coincides with the zone of active synthesis of new platelets (Kemp, '53). With the autoradiograms now available, however, it is impossible to distinguish whether the radioactivity is within the platelets or in the ground cytoplasm. Active enzymes could well be responsible for most 
of the uptake detected. It seems probable though that glycine would eventually be incorporated into growing yolk platelets. This could be investigated by injecting frogs with radioactive glycine and then continuing to feed them, whereupon oocytes would grow. If radioactivity were associated with the platelets present at the time of injection, it should in time be detectable in the interior because of the continued apposition of new platelets at the periphery.

\section{SUMMARY}

1. Forty-two adult female summer frogs were injected intrapleuroperitoneally with $10 \mu \mathrm{c}$ or $20 \mu \mathrm{c}$ of glycine-2- $\mathrm{C}^{14}$ in distilled water. Animals were sacrificed after 1 to 5 days, and samples of various organs were fixed in Bouin's fluid for subsequent sectioning or in trichloracetic acid for homogenization and isolation of proteins.

2. Autoradiograms of sections show that liver, lung, kidney, heart, brain and skeletal muscle incorporate glycine nearly uniformly, in contrast to stomach, intestine, skin and ovary, all of which exhibit distinct localization of uptake. Conspicuously high relative uptake of glycine was detected in mucosal epithelium of stomach and intestine, in epidermis and in peripheral cytoplasm of oocytes synthesizing yolk. Radioactivity remained chiefly peripheral even in oocytes at stage $\mathrm{Y}_{4}$, in which the eytoplasm was filled with yolk.

3. Specific activities of isolated proteins were higher in animals injected with $20 \mu \mathrm{c}$ than in those receiving $10 \mu \mathrm{c}$. The average order of incorporation as indicated by Geiger counts was: skin (highest), kidney, ovary, intestine, liver stomach and muscle. Rate of incorporation of glycine increases with growth of oocytes in the ovary. Determinations on ovary and kidney tissue indicate good correlation between radioactivity of isolated proteins and tissue radioactivity as demonstrated by counts made on sections.

4. It is believed that autoradiograms of tissues incorporating radioactive glycine may be used as a histochemical test to detect regions of active protein synthesis. 
5. Experiments of this kind are only very roughly quantitative and certainly cannot be used as evidence of the specific route of incorporation of radioglycine into protein or other high molecular material. Lower molecular weight material would probably not be registered because the material would not be fixed by the particular method used.

\section{LITERATURE CITED}

Abrams, R., E. HAMMARSt'En AND D. Shemin 1948 Glycine as a precursor of purines in yeast. T. Biol. Chem., 179: 429-430.

Barth, L. G., AND L. J. BarTir 1954 The energetics of development: a study of metabolism in the frog egg. Columbia University Press, Now York.

Bonsook, H. 1950 Protein turnover and incorporation of labeled amino aeids into tissue protein in vivo and in vitro. Physiol. Rev., 30: 206-219.

Borsook, H., C. L. Deasy, A. J. HAAgen-SMit, G. Keighlex and P. H. Lowy 1952 Incorporation in vitro of labeled amino acids into proteins of rabbit reticulocytes. J. Biol. Chem., 196:669-694.

Brachet, J. 1950 Chemical Embryology. Interseience Publ., Tne., New York.

Christensen, H. N., T. R. Riggs, H. Fischer and I. M. Palatine 1952 Amino acid concentration by a free cell neoplasm: relations among amino acids. J. Biol. Chem., 198: 1-15.

Christensen, H. N., T. R. Riggs And N. E. RAY 1952 Concentrative uptake of amino acids by erythroeytes in vitro. J. Biol. Chem., 194: 41-51.

Christensen, H. N., aND J. A. Streicher 1948 Association between rapid growth and elevated cell coneentrations of amino acids. I. In fetal tissues. J. Biol. Chem., 175: 95-100.

DENT, J. N., AND E. L. HunT 1952 An autoradiographic study of iodine distribution in larvae and metamorphosing specimens of Anura. J. Exp. Zool., 121: 79-97.

EAKIN, R. M., W. F. Berg AND P. B. KUTSKY 1950 Studies in protein metabolism of the amphibian embryo. II. Free amino acids. Proc. Soc. Exp. Biol. and Med., $75: 32-34$.

Fakin, R. M., P. B. Kutsky AND W. E. Berg 1951 Protein metabolism of amphibian embryo. III. Incorporation of methionine into protein of gastrulae. Proc. Soc. Exp. Biol. and Med., 78: 502-504.

Fioq, A., F. Gavosto and M. ERrFi 1954 a Incorporation in vitro de glycine1-(-14 dans los cellules individuelles de la moelle osseuse. Exp. Cell. Res., $6: 69-75$.

$1954 \mathrm{~b}$ Ineorporation in vivo de glyeine-1-C $\mathrm{C}^{14}$ dans les cellules individuelles de la moelle osseuse. Exp. Cell Res., 6: 238-239.

Frifiderg, F., and R. M. EAkin 1949 Studies in protein metabolism of the amphibian embryo. I. Uptake of radioactive glycine. J. Exp. Zool., 110: $33-46$. 
Friedrera, F., M. Shulman and D. M. Gremnberg 1948 The effect of growth on the incorporation of glyeine labeled with radioactive earbon into the protein of liver homogenates. J. Biol. Chem., 173: 437-438.

Grant, P. 1953 Phosphate metabolism during oogenesis in Rana temporaria. J. Exp. Zool., 194: 513-543.

Greenbekg, D. M., AND T. WinNick 1948 Studies in protein metabolism with compounds labeled with radioactive carbon. II. The metabolism of glycine in the rat. J. Biol. Chem., 173: 199-204.

KEMP, N. E. 1953 Synthesis of yolk in oocytes of Rana pipiens after induced ovulation. J. Morph., 98: 487-511.

1954 Incorporation of radioactive glycine into proteins of developing oocytes of Rana pipiens. Anat. Rec., 118: 317 (abstract).

1955 Incorporation of radioactive glycine into proteins of frog oocytes. Science, 121: 471-472.

Kutsky, P. B., R. M. Eakin, W. E. Berg and J. L. Kavanau 1953 Protein metabolism of anphibian embryo. IV. Quantitative changes in free and non-protein amino acids. J. Exp. Zool., 124: 263-278.

LEE, N. D., J. T. ANDERSON, R. MILler AND R. H. WILliams 1951 Incorporation of labeled cystine into tissue protein and subcellalar structures. J. Biol. Chem., 198: 733-742.

JeVine, M., AND H. TARVER 1950 On the synthesis and some applications of serine- $\beta-\mathrm{C}^{14}$. J. Biol. Chem., 184: 427-436.

MUELLer, G. C. 1953 Incorporation of glycine-2-(14 into protein by surviving uteri from a-estradiol-treated rats. J. Biol. Chem., 204: 77-90.

Winnick, T. M., F. Friedberg and D. M. Greenberg 1948 Studies in protein metabolism with compounds labeled with radioactive carbon. I. Metabolism of DL-tyrosine in the normal and tumor-bearing rat. J. Biol. Chem., 173: 189-197.

ZaMeonik, P. G., I. D. Frantz, JR., R. B. Loftfoteld and M. L. STephenson 1948 Ineorporation in vitro of radioaetive carbon from carboxyllabeled DL-alanine and glycine into proteins of normal and malignant rat livers. J, Biol. Chem., 175: 299-314.

ZAMECNIK, P. C., AND E. B. KELLER 1954 Relation between phosphate energy donors and incorporation of labeled amino aeids into protein. J. Biol. Chem., $909: 337-354$. 
Enlargements $(\times 3)$ of autoradiograms of adjacent sections of tissues of adult female frogs injected with glycine-2-2 $\mathrm{C}^{\mathrm{s}}$ and sacrificed three to 5 days later. Level of dosage and tine of sacrifice follow identifieation of tissue.

1 Liver of animal 8 (table 1) $-20 \mu \mathrm{c}$ glycine; sacrificed at 4 days. Radioactivity is uniform throughout gland.

2 Stomach of animal 1 (table 1) $-20 \mu \mathrm{c}$ glycine; sacrificed at 4 days. Localization of high uptake in mucosal epithelium; little uptake in submucosa; moderate uptake in tunica muscularis. Dark masses (M) at periphery result from highly radioactive tissue lying alongside the dorsal mesentery (above) and the gastro-hepatic ligament (left side). This tissue contains some pigmented colls but consists chicfly of closely-packed conneetive tissue cells, apparently proliferated in response to the presence of encysted cestode parasites.

3 Intestine of animal 10 (table 1) $-10 \mu \mathrm{e}$ glyeine; sacrificed at 4 days. Localization of uptake of glycine resembles that in stomach, i.e., high uptake in mucosal epithelium, little uptake in submneosa, moderate uptake in tunica muscularis. Larger, dark ring (V) at periphery is autoradiogram of section of pancreas surrounding hepatie portal vein. Smaller, gray ring (D) at periphery is autoradiogram of mucosal epithelium of ductus choledochus.

4 Lung of animal 11 (1953 experiment, Kemp, ' 55 ) - $20 \mu \mathrm{c}$ glyeine; sacrificed at 5 days. Mucosal epithelium exhibits high radioactivity. Wall of lung is so thin that contrast between epithelium and connective tissue cannot be demonstrated in this preparation.

5 Kidney of animal 8 (table 1) $-20 \mu \mathrm{c}$ glycine; sacrificed at 4 days. Radioactivity is nearly uniform throughout the gland.

6 Heart of animal 11 (1953 experiment, Kemp, '55) - $20 \mu \mathrm{c}$ glycine; sacrificed at 5 days. No conspieuous localization of radioactivity.

7 Brain of animal 11 (1953 experiment, Kemp, '55) - $20 \mu \mathrm{c}$ glycine; sacrificed at 5 days. No conspicuous localization of radioactivity.

8 Muscle of animal 10 (table 1 ) $-10 \mu \mathrm{c}$ glyeine; sacrificed at 4 days. Distribution of radioactivity is superficially uniform. Close examination of the autoradiogram, however, reveals tiny compartments with gray borders and lighter centers. This localization may indicate greater radioactivity at the periphery of individual muscle fibers.

9 Skin of animal 1 (table 1) $-20 \mu \mathrm{c}$ glycine; sacrificed at 4 days. Dark line indicates localization of high uptake in epidermis.

10 Ovary of animal 16 (table 1) $-20 \mu \mathrm{c}$ glycine; sacrificed at 4 days. Oocytes are at stage $Y_{0}$, prior to the beginning of the deposition of yolk. Dark gray circles reveal individual oocytes which have incorporated glycine. Dark rim of some of these circles suggests greater uptake of glycine at the periphery of oocyte.

11 Ovary of animal 4 (1953 experiment, Kemp, '55) - $10 \mu \mathrm{c}$ glycine; sacrificed at three days. Oocytes are in stage $Y_{z}$, when yolk fills the outer half of cytoplasm. Radioactivity is clearly peripheral.

12 Orary of animal 8 (table 1) $-20 \mu \mathrm{c}$ glycine; sacrificed at 4 days. Oocytes have reached stage $Y_{n}$, when yolk fills outer three-fourths of eystosome. Radioactivity is still localized at the periphery.

13 Ovary of animal 30 (table 1) $-10 \mu \mathrm{c}$ of glycine; sacrificed at 4 days. Docytes at stage $Y_{4}$ when yolk fills eytoplasm. Radioactivity is localized at the periphery. It is evident from a comparison of figures 10-13 that radioactive glycine is selectively incorporated into the active peripheral eytoplasm where now platelets are being synthesized. 


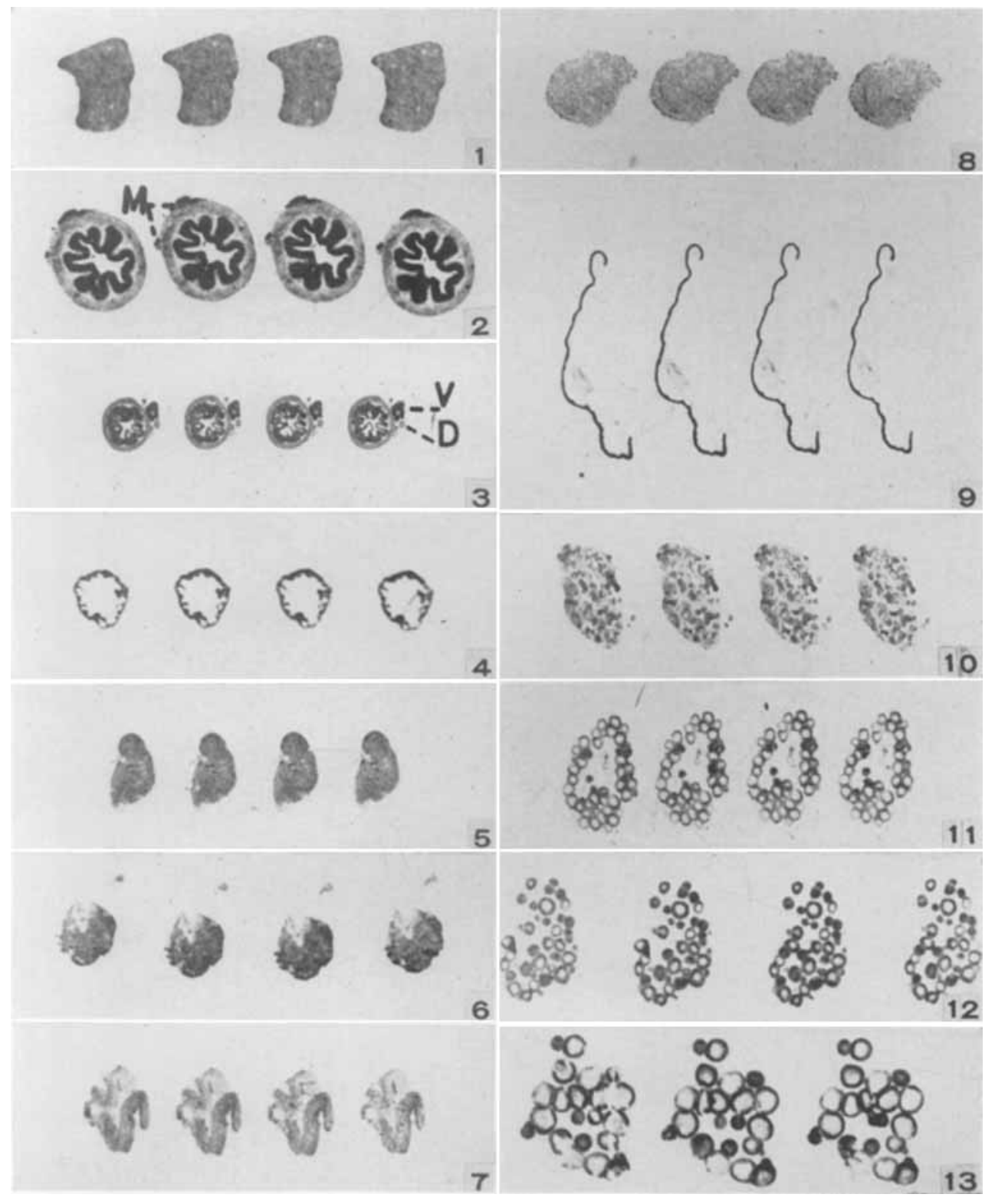

